\title{
aniki
}

Revista Portuguesa da Imagem em Movimento

Portuguese Journal of the Moving Image

\section{New Directions for 21st-Century Portuguese Cinema}

\author{
Hilary Owen
}

University of Manchester/ University of Oxford

hilary.owen@mod-langs.ox.ac.uk

https://orcid.org/0000-0001-6648-0762

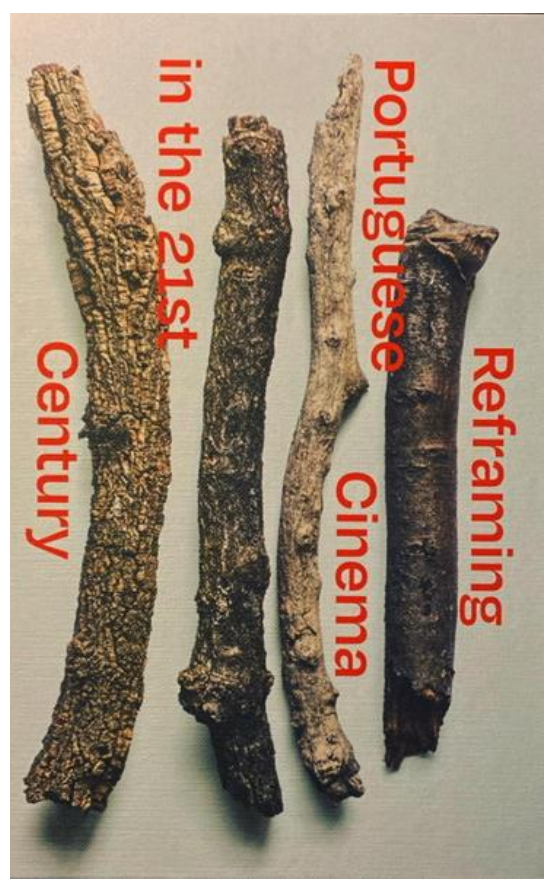

\begin{abstract}
Ribas, Daniel and Cunha, Paulo (eds). 2020. Reframing Portuguese Cinema in the 21st Century. Volume 1. Lisboa: Agência da Curta Metragem $229 \quad$ pp $\quad$ ISBN 9789729857478.
\end{abstract}

Reframing Portuguese Cinema in the 21st Century, volume 1, edited by Daniel Ribas and Paulo Cunha, represents a considerable tour de force. It has begun the difficult and vital task of mapping, defining and setting the critical agenda for an epoch of cinema in Portugal, during a time of complex and challenging transformation. I have no doubt that it will become a fundamental work of reference for all of us teaching Portuguese cinema of this period at university and college level, affording a high degree of necessary historical, political and industry 
contextualisation as well as exemplifying a series of rich and intricate close readings, and axes of comparison. It will also helpfully establish the terms in which specific contemporary debates and discussions can now be conducted, perhaps most influentially, the consolidation of austerity cinema into a clearly defined film corpus, superseding $1990 \mathrm{~s}$ cinema of precarity, in many ways, at the country's most clearly identifiable cutting edge.

The introduction by Daniel Ribas and Paulo Cunha, "Notes Towards a Brief History of Portuguese Cinema in the 21st Century", establishes some important critical and historical parameters, notably the multifaceted impact of the post-banking crash economic crisis, the continuity of a predominantly auteurist cinema, and the rising interand transnationalisation of production and co-production (whilst maintaining, nonetheless, an intriguing degree of national distinctiveness, derived partly as the authors demonstrate, from Portugal's ongoing investment in auteurism). Within this scenario, in which a properly "national cinema" idea becomes an ever more mobile and unstable frame of analysis, they highlight two paradigm-shifting and highly influential cinematic moments, which go on to inform many of the individual chapter readings, namely: the emergence of the Geração Curtas (indeed, this volume was brought out partly to celebrate the 20th anniversary of its publisher, the Agência da Curta Metragem), and Pedro Costa's 2000 landmark, No Quarto da Vanda, which radically redrafted the groundrules of Portuguese political cinema for the digital era. In the remainder of their introduction and in the chapters they describe, Ribas and Cunha do an excellent job of demonstrating the generic and thematic diversity of Portuguese cinema, charting not only high-profile fiction films such as Miguel Gomes's Tabu, but also the proliferation of groundbreaking documentary production, as well as noting the strong trend for docufictional hybridisation of rigid genre definition, and the state of the art in animation. They also pay much-needed attention to the rise of intermedial and intertextual work and to the country's changing contexts of screening, with greater prominence now afforded to the "non-commercial exhibition circuit especially through film festival and local film societies" (p. 20).

The thirteen contributors come from a range of national, professional and cultural backgrounds, and this diversity is an enormous strength. The first chapter by Iván Villarmea Álvarez explores representations of 
crisis in Portuguese austerity cinema focussing on, but also taking us beyond, the now relatively well-worn paths of A Fábrica de Nada, São Jorge and Mil e Uma Noites, to integrate thoughtful readings of documentaries too, such as Manuel Mozos's Ruínas and Daniel Blaufuks's Um Pouco Mais Pequeno que o Indiana. Tiago Baptista makes a very important contribution to the growing field of archive studies in relation to Portuguese documentaries, drawing exciting parallels between the denaturalisation of historiographical narratives and the deconstruction of film image, and focussing on Margarida Cardoso's Kuxa Kanema, Susana de Sousa Dias's Natureza Morta, and João Canijo's Fantasia Lusitana. Carmen Gray returns us to the subject of austerity cinema, with a highly engaging and beautifully written chapter exploring the political deployments of fantasy, daydreaming and magical realism, focussing primarily on Carlos Conceição's Serpentarius, Jorge Jácome's Past Perfect, Miguel Gomes's Mil e Uma Noites, and Pedro Pinho's A Fábrica de Nada. Her readings of these latter two rank among the best work published anywhere on these two films. Cíntia Gil gives a thorough and useful update on, and set of suggestions for, the politics and economics shaping the work of Portuguese production companies and the contemporary state of the industry, through the lenses afforded by Deleuzian "minor cinema", and the changing role of the state as it territorialises funding, distribution and exhibition. Pascale Cassagnau's piece interfaces productively with queer theory, particularly the work of Renate Lorenz, to take us on a theoretically nuanced and sophisticated "Journey through Portuguese Contemporary Art Cinema" with the "Pedro Costa: Company" exhibition at the helm, setting the scene for exploring a rich array of others under a series of thematic headings including animals, archives and labyrinths. Olivier Cotte's chapter on animation carefully unpacks the work of figures such as Regina Pessoa, Isabel Aboim Inglez, Abi Feijó and José Miguel Ribeiro, making their technical achievements helpfully accessible and clear to the general film reader.

Adrian Martin's chapter on Pedro Costa, taking its cue from Italo Calvino's The Uses of Literature, to explore "realities of level" rather than "levels of reality", accomplishes the impressive task of bringing fresh and insightful analyses to the whole of Pedro Costa's oeuvre, emphasising his commitment to pragmatic bricolage of objects, and including his lesser-known shorts, as well as conceptualising the full opus clearly as an interconnected and evolving body of work, without 
reduction or over-simplification. This chapter is definitely a must for undergraduate film course bibliographies. Haden Guest's chapter covers the five Asian films of João Pedro Rodrigues and João Rui Guerra da Mata. Guest's original angle throws light on some of the lesser-known byways of their documentary and fiction cinema, highlighting a "restless transformational desire" (p. 146) which is also common to queer cinema, showing how their work typifies the shift away from foregrounding identity and thematics, to embrace "an intrinsic logic of alterity and otherness" (p. 146). Following this through in relation to the Asian films and taking in some useful comparisons with other contemporary radical queer filmmakers, Guest goes on to deliver a fascinating reading of the charged role played by the queer and changeling body in A Última Vez que Vi Macau.

Animation is central again to the chapter by Carolina López Caballero and Adrián Encinas, working on Regina Pessoa and José Miguel Ribeiro, making an interesting axis of comparison and further exposition in relation to the chapter by Cotte. Roger Koza takes an interesting and rarely explored angle on human spirituality, secular faith and elements of ritual as they appear and develop across the various works of Miguel Gomes, including the shorts. Martin Pawley opens up the rather lesserknown work of Sandro Aguilar exploring themes of light and darkness, nocturnal and diurnal. Leo Goldsmith provides a carefully elucidated vade mecum for Filipa César's essay films, with specific reference to "soft montage", a term he takes from Harun Farocki, as well as other characteristic techniques. And finally, Angela Prysthon gives a lively tour d'horizon of João Salaviza, with a particular focus on the way he constructs space in relation to the human body.

In light of the volume's very wide frame of reference, an index would have been a useful aid to the reader and teacher. So too would the inclusion of some visual images to accompany more complex instances of screen analysis. However, this will almost certainly have been a decision by the publishers not the editors and was most likely a question of cost. Many of the chapters are written by scholars working outside the Portuguese academic establishment, coming from art history, journalism, curating, filmmaking and archiving, which means that many chapters are richly cross-referenced with other cinema traditions, movements and innovations. No library, lecturer or student with a serious commitment to Portuguese cinema can afford to be without this volume, whether they are working in lusophone studies 
per se or in film studies as conventionally conceived. The coordinates of a 21st-century Portuguese film industry and its differently national, increasingly trans- and international, aesthetic, thematic and socioeconomic coordinates are brought very clearly into focus here, both in abstract and in concrete forms, through a series of helpful and generically diverse exemplars and case studies. It is very good news that a second volume is already planned by these two editors, and it is to be hoped that more will follow. The excellent critical analysis, the consistent quality of the contributors and the breadth of generic scope to be found here have set the standard exceedingly high. And I am confident we will see this standard maintained in the future, in the safe hands of two such skilled, experienced and prolific co-editing scholars as Daniel Ribas and Paulo Cunha.

Given that volume two is planned, as we are informed at the end of the introduction, I will permit myself here to make one suggestion for it, based on my considerations of volume one. Reframing Portuguese Cinema in the 21st Century clearly and productively embraces a 21stcentury political legacy in terms of how Portugal's contemporary filmmakers treat issues such as austerity, precarity and globalization. Feminism, gender, race and decoloniality, however, seem curiously absent or tangential at best in this volume. The introduction tells us, "as far as representation goes, it must be pointed out that the 21st century has given some timid signs of correcting historic wrongs. The presence of women in technical crews has grown exponentially, as well as the number of women directors; another clear example is the growing visibility, on their own merits, attained by filmmakers from the African diaspora" (p. 23). Yet in this era of \#MeToo, and despite now established traditions of feminist and gender-based readings of cinema, not peculiar only to Hollywood, film studies, or the academic anglosphere, it cannot be other than striking that volume one contains no sustained or significant consideration of any film by a woman director that is not a documentary, a short or a work of animation. An unfortunate side-effect of this is to reinforce a stereotype whereby women are discounted as directors of full-length feature films often including, sadly, by funding bodies, despite the extraordinary work that the 21st century has witnessed by Teresa Villaverde, Margarida Gil, Margarida Cardoso and Rita Azevedo Gomes, to name only a few. The risk here is that of a self-fulfilling prophesy, whereby each succeeding historical periodization builds upon and reinforces the normatively white male schools of auteurist criticism and structural 
organisation which preceded it. But this does not have to be the case. Ribas and Cunha and their superb cast of international authors have undoubtedly set an agenda for 21st-century Portuguese film analysis, and women and ethnic minorities deserve to be part of it. Portuguese cinema has no reason to remain "timid". There are many proud and important things to say about the politics and the practices of femaledirected and feminist, as well as ethnic minority, anti-colonial and black-authored cinema in Portugal, in order to break open the hegemonic history models that structure film periodization, and to promote the imperatives of social justice in the cinema industry, by diversifying that too. 